\title{
Kebijakan Satu Peta (One Map Policy) Mencegah Konflik di Bidang Administrasi Pertanahan
}

\author{
Ana Silviana \\ Fakultas Hukum, Universitas Diponegoro \\ silvianafhundip@gmail.com
}

\begin{abstract}
This study aims to study normatively to see the implementation of the one map policy in the land sector and prevent land administration conflicts. The research method used is normative legal research. The results of the study show that the One Map Policy or One Map Policy in order to realize the Land Administration Order is still a roadblock, because there are still many problems that arise related to ownership disputes and duplicate disputes as evidence of land ownership. In an effort to accelerate the development of quality spatial data, efforts have been made through the implementation of land registration to ensure the legal certainty of land rights.
\end{abstract}

Keywords: One Map Policy, Agrarian Conflict, Land Administration

\begin{abstract}
Abstrak
Penelitian ini bertujuan untuk mengkaji secara normatif untuk melihat implementasi kebijakan one map policy di bidang pertanahan dan mencegah konflik administrasi pertanahan. Metode penelitian yang digunakan adalah penelitian hukum normatif. Hasil penelitian menunjukan bahwa Kebijakan Satu Peta atau One Map Policy dalam rangka mewujudkan Tertib Administrasi Pertanahan masih dipersimpangan jalan, karena masih banyaknya permasalahan yang muncul terkait dengan sengketa kepemilikan dan sengketa duplikasi alat bukti kepemilikan tanah. Dalam upaya untuk percepatan pembangunan data spasial yang berkualitas telah dilakukan usaha-usaha melalui penyelenggaraan pendaftaran tanah untuk menjamin kepastian hukum hak-hak atas tanah.
\end{abstract}

Kata Kunci: Kebijakan Satu Peta, Konflik Agraria, Administrasi Pertanahan

\section{A. Pendahuluan}

Kebijakan Satu Peta atau One Map Policy (OMP) adalah kebijakan Pemerintah dalam rangka untuk mewujudkan tata kelola hutan dan pertanahan yang baik sebagai sarana untuk mencegah konflik penguasaan lahan di Indonesia. OMP diperlukan, pada saat Pemerintahan Presiden Susilo Bambang Yudhoyono meninta data luas lahan mengenai Peta Vegetasi, yang kemudian oleh Unit Kerja Presiden Bidang Pengawasan dan Pengendalian Pembangunan (UKP-PPP atau UKP4) dicari data tersebut melalui Kementrian Kehutanan dan Lingkungan Hidup , namun ternyata setelah digabungkan 
antara data dari UKP4 dengan data dari Kementrian Kehutanan dan Kementrian Lingkungan Hidup ternyata tidak sama. Presiden pada waktu itu (2010) mengamanatkan kepada Badan Informasi Geospasial (BIG) untuk membuat OMP untuk menyatukan seluruh informasi peta yang diproduksi dari berbagai sektor ke dalam satu peta secara integratif, sehingga tidak terdapat perbedaan atau tumpang tindih formasi dalam peta yang ditetapkan oleh BIG. Dalam hal ini Peta BIG dijadikan sebagai acuan standar.

Dalam rangka untuk mendorong penggunaan Informasi Geospasial guna pelaksanaan pembangunan, maka pada Tahun 2016 tepatnya tanggal 1 Februari 2016 Presiden Joko Widodo menerbitkan Peraturan Presiden Nomor 9 Tahun 2016 tentang Percepatan Pelaksanaan Kebijakan Satu Peta (KSP) pada Tingkat Ketelitian Peta Skala 1:50.000 yang mengacu pada referensi geospasial, satu standar, satu basis data, dan satu geoportal guna percepatan pelaksanaan pembangunan nasional. ${ }^{1}$

Dibidang Pertanahan Presiden Joko Widodo juga meminta kepada Kementrian Agraria dan Tata Ruang/Badan Pertanahan Nasional (ATR/BPN) untuk segera mewujudkan peta tunggal (OMP) terkait kebijakannya. ${ }^{2}$ Kebijakan OMP tersebut sejalan dengan semangat reforma agraria yang menjadi program prioritas pemerintah.

Konflik pertanahan yang sering terjadi disebabkan oleh ketidakselarasannya dalam administrasi pertanahan. Layanan administrasi pertanahan belum mendukung tersedianya data yang valid serta akurat, misalnya suatu kawasan dikalim sebagaui kawasan hutan, namun fakta empirik di kawasan tersebut telah menjadi permukiman. Di sinilah pentingnya administrasi pertanahan, karena administrasi pertanahan yang baik akan menghapuskan kesenjangan sosial di masyarakat. Penyebab terjadinya konflik pertanahan di Indonesia adalah pertama akibat kemiskinan dan distribusi kepemilikan tanah yang tidak merata. Kedua jumlah bidang tanah yang terdaftar baru $50 \%$ dari 126 juta bidang. Ketiga terdapat alas hak yang bukti kepemilikan tanahnya beragam, dan belum terdaftar menjadi sertipikat tanah. Tidak tertibnya administrasi pengelolaan aset tanah, baik dari pemerintah, pemerintah daerah, Badan Usaha Milik Negara (BUMN), dan Badan Usaha Milik Daerah (BUMD), serta putusan pengadilan yang berbeda-beda atas bidang tanah yang sama, juga menjadi alasan munculnya konflik pertanahan.

\footnotetext{
1 "Perpres No.9/2016: Pemerintah Bentuk Tim Percepatan Kebijakan Satu Peta", Humas Sekretariat Kabinet Republik Indonesia, diposting pada: 22 Feb 2016, diunduh 6 Mei 2019, 12.50 WIB

2 Cegah Sengketa Lahan, Jokowi Minta "One Map Policy" Segera Dibuat, Kompas.com, Rabu, 24 Agustus 2016|16.01 WIB, diunduh 6 Mei 2019, 13.00 WIB.
} 
Tulisan ini akan mengkaji secara normatif untuk melihat implementasi kebijakan OMP di bidang pertanahan dan mencegah konflik administrasi pertanahan.

\section{B. Pembahasan}

\section{Kebijakan Satu Peta (One Map Policy) di Bidang Pertanahan}

Kebijakan Satu Peta (KSP) atau One Map Policy (OPM) adalah arahan strategis dalam terpenyhunya satu peta yang mengacu pada satu referensi geospasial, satu standar, satu basis data, dan satu geoportal pada tingkat pada tingkat ketelitian peta skala 1:50.000.

Latar belakang dikeluarkannya kebijakan pembuatan Satu Peta Tunggal (OMP) adalah bahwa Informasi Geospasial Tematik (IGT) yang ada selama ini ternyata masih saling tumpang tindih satu sama yang lainnya. Kondisi seperti ini sangat menyulitkan dalam mendukung pemanfaatan ruang dan penggunaan lahan untuk pengembangan kawasan dan infrastruktur. Kondisi ini sangat merugikan karena tanpa dipadukan / disinkronkan antara peta yang satu dengan peta yang lainnya untuk suatu kepentingan pembangunan pada akhirnya suatu perencanaan pembangunan akan mengalami kegagalan dan dengan sendirinya pembangunan wilayah tidak pernah ada, bahkan bisa jadi menyebabkan kerusakan lingkungan.

Kebijakan Satu Peta (OMP) adalah bertujuan untuk membenahi sistem pemetaan tematik nasional dan segaligus peta dasarnya, khususnya untuk skala 1:50.000. Dari sisi lain Kebijakan Satu Peta (OMP) juga dapat dipandang bahwa sistem pemetaan nasional yang menghasilkan informasi geospasial nasional, selama ini ternyata belum bisa sepenuhnya dimanfaatkan untuk mendukung pembangunan nasional. ${ }^{3}$

OMP juga berfungsi sebagai acuan perbaikan data Informasi Geospasial Tematik (IGT), acuan perencanaan pemanfaatan ruang skala luas yang terintegrasi dalam dokumen Rencana Tata Ruang. OMP juga berfungsi sebagai: ${ }^{4}$ Acuan perbaikan IGT masing-masing sektir; dan Acuan perencanaan pemanfaatan ruang skala luas yang terintegrasi dalam dokumen Rencana Tata Ruang.

\footnotetext{
3 Aloysius Susanto, Kebijakan Satu Peta Momentum Reformasi Penyelenggaraan Informasi Geosapasial Nasional, Jurnal, Seminar Nasional, 2016, hlm.24

4 Tentang Percepatan Kebijakan Satu Peta (PKPS), Sekretariat Tim Percepatan Kebijakan Satu Peta, satupeta.go.id, diunduh 5 Mei 2019, 12.34 WIB
} 
Untuk merealisasikan tercapainya OMP, diselenggarakanlah Rencana Aksi Percepatan Pelaksanaan Kebijakan Satu Peta pada kurun waktu 2016 - 2019. Rencana Aksi tersebut dengan melakukan langkah-langkah perbaikan IGT yang ada, integrasi data IGT dengan data Informasi Geospasial Dasar (IGD), sinkronisasi antar IGT, dan rekomendasi serta fasilitas penyelesaian masalah IGT. (Perpres No. 9 Tahun 2016)

Proses perbaikan/pembenahan IGT melalui OMP tentu tidaklah mudah karena sejak awal masing-masing kementrian membuat peta menurut versinya sendiri dan bersifat sektoral, sehingga upaya pembenahannya tidak sekedar proses kartografi (penggambaran data IGT di atas kerta), tetapi juga proses-proses substansial lainnya, seperti pengumpulan data, proses data lapangan, visualisasi data pada peta, dan kerangka atau peta dasar yang digunakan untuk visualisasi dan data tematik perlu diteliti dan dikaji ulang. Tanpa penelitian dan pengkajian terhadap hal-hal tersebut akan menghasilkan peta yang hanya sinkron di atas kertas namun tidak sinkron dengan kenyataan di lapangan. ${ }^{5}$

Tiga kegiatan utama dari percepatan kebijakan satu peta (OMP) dilakukan secara berunrutan yaitu: ${ }^{6}$

1. Kompilasi, merupakan kegiatan mengumpulkan Informasi Geospasial Tematik (IGT) yang dimiliki oleh Kementrian/Lembaga/Pemerintah Daerah. IGT yang dikompilasi adalah 85 peta tematik sesuai dengan lampiran rencana aksi Perpres No.9/2016.

2. Integrasi, merupakan kegiatan koreksi dan verifikasi IGT di atas peta dasar Informasi Geospasial Dasar (IGD).

3. Sinkronisasi, adalah kegiatan penyelarasan antara IGT yang telah selesai integrasi, termasuk di dalamnya penyelesaian permasalahan tumpang tindih antgara IGT.

Informasi Geospasial (IG) yang diatur dalam Undang-Undang Nomor 4 Tahun 2011 tentang Informasi Geospasial adalah data geospasial yang sudah diolah sehingga dapat digunakan sebagai alat bantu dalam perumusan kebijakan, pengambilan keputusan, dan/atau pelaksanaan kegiatan yang berhubungan

\footnotetext{
${ }^{5}$ Ibid, hlm.25.

6 Tentang Percepatan Kebijakan Satu Peta (PKPS), Sekretariat Tim Percepatan Kebijakan Satu Peta, satupeta.go.id, diunduh 5 Mei 2019, 12.34 WIB
} 
dengan ruang kebumian. Data Geospasial adalah data tentang lokasi geografis, dimensi atau ukuran, dan/atau karakteristik objek alam da/atau batuan manusia yang berada di bawah, pada, atau di atas permukaan bumi.

Geospasial atau ruang kebumian adalah aspek keruangan yang menunjukkan lokasi, letak, dan posisi suatu objek atau kejadian yang berada di bawah, pada, atau di atas permukaan bumi yang dinyatakan dalam sistem koordinat tertentu.

Di bidang pertanahan percepatan kebijakan satu peta (OMP) diharapkan dapat menyelesaiakan permasalahan tumpang tindih pemanfaatan ruang dan penatagunaan tanah di Indonesia. hingga kini pengembangan kawasan dan infrastruktur masih terhambat akibat tumpang tindih data informasi geospasial tematik, sehingga memperlambat pembangunan dan meminimalisir sengketa tanah yang kerap terjadi, demikian kata Direktur Survei dan Pemetaan Tematik Kemnetrian ATR/Badan Pertanahan Nasional Perdananto Ariwibowo. ${ }^{7}$

Dalam hal ini peran dari Kemnetrian ATR/BPN dalam menjalankan Kebijakan satu peta (OMP) adalah sebagai wali dari 12 tema, dan merupakan salah satu simpul jaringan yang merupakan bagian dari jaringan Informasi Geospasial Nasional atau JIGN. Di bidang pertanahan Kebijakan Satu Peta (OMP) akan mengintegrasikan pemakaian data yang akan digunakan untuk 12 tema antara lain peta HGB, HGU, HPL, Izin Lokasi, RTRW, dan lahan sawah.

Pelaksanaan OMP akan berguna bagi Pemerintah Pusat (Kementrian / Lembaga) dan pemerintah daerah dalam berbagai data dan Informasi Geospasial untuk melakukan sinkronisasi dan perbaikan data geospasial sehingga menjadi acuan bagi seluruh Kementrian atau Lembaga dan pemerintah daerah dalam mengeluarkan perijinan maupun kebijakan.

Target dari Kementrian ATR/BPN dalam level regulator menargetkan kebijakan OMP nantinya dapat diakses oleh seluruh lapisan masyarakat dengan meluncurkan portal resmi terkait geospasial.

Berdasarkan Peraturan Presiden Nomor 20 Tahun 2015 tentang Badan Pertanahan Nasional tugas pokok BPN adalah melaksanakan tugas pemerintah dibidang pertanahan sesuai dengan ketentuan peraturan perundang-undangan. Dalam menjalankan tugasnya tersebut BPN berfungsi di antaranya: a.

\footnotetext{
${ }^{7}$ Kebijakan Satu Peta Minimalkan Sengketa Tanah, DKI Jakarta, Deputi Gubernur Bidang Tata Ruang Dan Lingkungan Hidup, taruhl.com > kliping, 3 September 2018, diunduh 5 Mei 2019, 12.00 WIB
} 
Penyusunan dan penetapan kebijakan di bidang pertanahan, b. Perumusan dan pelaksanaan kebijakan dibidang survei, pengukuran, dan pemetaan, c. Perumusan pelaksanaan kebijakan dibidang penetapan hak atas tanah, pendaftaran tanah, dan pemberdayaan masyarakat, dan d. Perumusan pelaksanaan kebijakan bidang pengendalian dan penanganan sengketa dan/atau perkara pertanahan.

Manfaat OMP yang lain adalah setiap tataran pemerintahan dengan ada kebijakan satu peta, akan menggunakan satu peta dasar yang sama. Karena menggunakan satu peta bidang yang sama, lahan yang telah dikeluarkan izin pengelolaannya, tidak bisa dikeluarkan izin pengelolaan pada bidang tanah yang sama. Artinya,bisa menghindari tumpang tindih penerbitan izin atas pengelolaan lahan. Misalnya sudah diberikan izin pertambangan, ternyata diberikan juga izin perkebunan (izin yang tumpang tindih). Diharapkan dengan terbentuknya OMP maka tidak terjadi lahi hal tersebut. Lebih lanjut ia menjelaskan, one map policy ini akan tersaji dalam 85 peta tematik yang berisi informasi sesuai kegunaan masing-masing. Contohnya peta infrastruktur. Peta ini bisa mengetahui di mana jalur pipa gas, jalur kabel serat optik dan infrastruktur lainnya. Harapannya, tidak ada lagi pembangunan infrastruktur yang saling berbenturan. Contoh lain, adalah peta potensi sumberdaya alam yang menyajikan informasi di mana saja lokasi sumber daya alam tersedia, apa jenis sumber daya alam yang ada hingga status pengelolaannya. Sehingga, dengan harapan tidak terjadi lagi penerbitan izin pengelolaan kawasan di satu lokasi yang sama. Saat ini, dari 85 peta tematik yang tengah disusun, 27 peta di antaranya sudah rampung, 57 peta lainnya masih dalam proses kompilasi atau pengumpulan informasi dan tinggal 2 yang masih belum disusun. Peta yang belum selesai misalnya peta kawasan ulayat, dan peta desa.

Untuk mewujudkan OPM, gerakan melakukan pemetaan wilayah adat sebetulnya sudah dimulai pada Tahun 1996 yang dilakukan oleh Masyarakat Hukum Adat (MHA) bersama Organisasi Masyarakat Sipil (OMS) dan Ornop. Namun, peta-peta tersebut tersebar diberbagai OMS yang ada di Indonesia. ketersediaan data spasial dalam bentuk peta dan data sosial merupakan bagian penting dalam komunikasi untuk membangun kesadaran, pemahaman dan dukungan publik dalam advokasi untuk mendapatkan pengakuan dan perlindungan bagi masyarakat hukum adat dan wilayah adatnya. 
Perkembangannya Aliansi Masyarakat Adat Nusantara (AMAN), Jaringan Kerja Pemetaan Partisipatif (JKPP), Forest Wacht Indonesia (FWI) mendirikan Badan Registrasi Wilayah Adat (BRWA).

BRWA adalah badan yang diharapkan berperan untuk mengkomunikasikan keberadaan masyarakat adat, wilayah adat serta partisipatif wilayah adat kepada pemerintah dan OMS dalam rangka pengakuan dan perlindungan masyarakat adat di Indonesia. BRWA juga menjadi tempat untuk pendaftaran wilayah adat sekarang ini. Sistem Pendaftaran (Registrasi) untuk masyarakat dan sistem Verifikasi disiapkan untuk membantu masyarakat mempersiapkan informasi yang diperlukan. Proses Registrasi dan verifikasi wilayah adat oleh BRWA adalah upaya untuk mendokumentasikan secara sistematis atas keberadaan masyarakat adat dan wilayah adatnya dalam upaya pengakuan dan perlindungan masyarakat hukum adat di Indonesia.

Hasil pemetaan pastisipatif wilayah adat yang dilakukan oleh BRWA, AMAN dan JKPP diserahkan kepada Kementrian Lingkungan Hidup dan Kehutanan (KLHK) Kemnetrian Agraria Tata Ruang/Badan Pertanahan Nasional (ATR/BPN) dan Badan Informasi Geospasial (BIG). Peta wilayah Adat yang sudah terdaftar pada BRWA dan diserahkan kepada pemerintah sebanyak 777 peta wilayah adat seluas 9.3 juta hektar. $^{8}$

Badan Informasi Geospasial (BIG) adalah lembaga pemerintah non kementrian Indonesia yang bertugas melaksanakan tugas pemerintahan di bidang informasi geospasial. Dalam rangka mengurangi konflik agraria untuk menuju OMP, BIG telah meluncurkan aplikasi pemetaan partisipatif. Aplikasi ini dapat membantu publik untuk memetakan sendiri lingkungan dan wilayahnya baik diperkotaan, perdesaan maupun di kawasan hutan. Program pemetaan partisipatif akan memudahkan komunitas masyarakat, pemilik modal dan pemerintah daerah mendaftarkan lahan hutan berdasarkan analisis geospasial. ${ }^{9}$

Seluas 120 Juta hektar wilayah Indonesia, 61\% tanah daratnya adalah "tanah hutan” yang diklaim dan dikelola oleh Departemen Kehutanan. Menurut Boedi Harsono sebidang tanah yang tumbuh hutan di atasnya, penguasaan tanahnya diatur dalam Hukum Tanah dan pengelolaan haknya diberikan kepada

\footnotetext{
${ }^{8}$ Kasmito Widodo, Kepala BWRA, Jakarta Desember 2017

9 “Kebijakan Satu Peta, Pemetaan Kawasan Hutan Libatkan Publik, Bisnis Indonesia, Selasa 26 Agustus 2014.
} 
Kementrian Kehutanan seperti yang diamanatkan oleh UU Kehutanan. Pemberian dan pengakuan hak-hak atas tanah akan diterbitkan oleh BPN dengan menggunakan Hukum Pertanahan. ${ }^{10}$

Di sisi lain Maria Sumardjono (2001) pada saat proses revisi Undang Undang Pokok Kehutanan No 5 tahun 1967 mengatakan bahwa: "Ruang lingkup (Rancangan) Undang-undang Kehutanan seharusnya dibatasi pada pengaturan tentang pemanfaatan sumber daya hutan. Penentuan kawasan hutan diperlukan untuk membatasi luasnya kewenangan pengelolaan pemanfaatan sumber daya hutan dan tidak dimaksud untuk membrikan wewenang untuk mengatur tentang penguasaan tanah di dalam kawasan hutan tersebut." Pemberian hak untuk memanfaatkan kawasan hutan (HPH \& HPHTI) dilakukan oleh Departemen Kehutanan, sedangkan pemberian hak atas tanah, misalnya HGU dan lain-lain dilakukan oleh BPN. Dengan pemahaman dua argumentasi pakar hukum pertanahan ini maka Departmen Kehutanan hanya dapat memberikan hak pengusahaan dan hak pemungutan hasil hutan, sedangkan segala proses yang berkaitan dengan penguasaan atas tanah dilakukan oleh instansi lain (BPN). Dengan pemahaman dua argumentasi pakar hukum pertanahan ini maka Departmen Kehutanan hanya dapat memberikan hak pengusahaan dan hak pemungutan hasil hutan, sedangkan segala proses yang berkaitan dengan penguasaan atas tanah dilakukan oleh instansi lain (BPN). Penataan batas kawasan hutan tidaklah menjadi batasan untuk tidak menggunakan Undang Undang Pokok Agraria No 5 Tahun 1960, sebagaimana lazim dipraktekan saat ini. $^{11}$

\section{Implementasi Kebijakan Pertanahan Menuju One Map Policy (OMP)}

Pemetaan partisipatif adalah pemetaan yang dilakukan oleh kelompok masyarakat mengenai tempat/wilayah dimana mereka hidup. Masyarakat yang hidup dan bekerja di temapt itulah yang memiliki pengetahuan mendalam mengenai wilayahnya, sehingga hanya mereka yang bisa membuat peta secara

\footnotetext{
${ }^{10}$ Boedi Harsono, Sejarah Pembentukan Undang-Undang Pokok Agraria, Isi dan Pelaksanaannya, (Jambatan : Jakarta, 2008), hlm 9-16

${ }^{11}$ Chip Fay \& Martua Sirait, "Kerangka Hukum Negara dalam Mengatur Agraria dan Kehutanan Indonesia: Mempertanyakan Sistem Ganda Kewenangan atas Penguasaan Tanah", ICRAF Southeast Asia Working Paper, No. 2005_3, Paper dipresentasikan dalam "The International Conference on Land Tenure", Jakarta, 11-13 October 2004.
} 
lengkap dan akurat mengenai sejarah, tata guna lahan, pandangan hidup, dan harapan masa depan. ${ }^{12}$

Kebijakan pemanfaatan tanah yang buruk setta ditambah proses administrasi pertanahan yang tidak pernah selesai yang menyebabkan masyarakat Indonesia dihadapkan pada dilema yang sangat sulit. Masyarakat jelkas akan sangat sulit jika hanya mengandalkan kelembagaan Negara. sudah saatnya masyarakat untuk melakukan pemetaan, inventarisasi dan perencanaan pemanfaatan tanah karena masyarakat memiliki peta mental (mental map) yang secara lisan selama ini berkembang dan dimanfaatkan sebagai konsensus dalam tata cara kehidupan di antara sesamanya, akan tetapiu peta mental saja tidak memadai. Banyak pengetahuan yang hilang karena transfer yang tidak sempurna kepada gerenasi berikutnya. Pengetahuan-pengetahuan dan klaim-klaim yang hanya berupa pengetahuan lisan atau peta mental ternyata secara formal tidak diakui. ${ }^{13}$ Faktanya kebijakan yang ada juga menunjukkan kurangnya penghargaan terhadap pengetahuan-pengetahuan lokal dan peta mental sehingga masyarakat perlu mencoba menggambarkan petanya sendiri dan kemudian memanfaatkan sepenuhpenuhnya peta tersebut. Ide-ide tentang bagaimana masyarakat membuat petanya sendiri ini yang kemudian dikenal dengan pemetaan partisipatif.

Pemetaan partisipatif mulai berkembang di Indonesia pada Tahun 1990 yang dilakukan oleh lembaga-lembaga yang bekerja di kawasan konservasi. Penggunaan metode pemetaan partisipatif kemudian semakin meluas pada lembaga-lembaga yang menggunakannya maupun isu-isu yang menjadi dasar penggunaan pemanfaatan pasrtisipatif.

Manfaat pemetaan partisipatif adalah $:^{14}$

1. Meningkatkan kesadaran, sebagian atau seluruh anggota masyarakat akan tumbuh kesadarannya tentang hak-hak mereka atas tanah dan sumber daya alam;

2. Peta bisa digunakan sebagai media negosiasi dengan pihak lain, karena dengan peta menjadi jelaslah bagaimana wilayah itu dimanfaatkan oleh masyarakat dan siapa saja yang berhak atas wilayah itu;

\footnotetext{
${ }^{12}$ Hepi Hapsari, Pemetaan Partisipatif Potensi Desa, (Surabaya: Jurnal Teknik Geomatikal, Instiutut Teknologi Surabaya, 2017), hlm.1

${ }^{13}$ Sulaiman Daud, Pemetaan Partisipatif, (jurnal Wacana, Edisi 15, Academia Edu, 2013), hlm.4

${ }^{14}$ Ibid, hlm 7
} 
3. Proses pemetaan partisipatif menumbuhkan semangat untuk menggali pengetahuan lokal, sejarah asal-usul, sistem kelembagaan setempat, pranata hukum setempat, identifikasi sumber daya yang dimiliki tersebut;

4. Peta mempermudah pihak luar memahami pengurusan wilayah itu, dan sekaligus mempermudah pengakuan di pihak luar;

5. Menumbuhkan partisipasi masyarakat, baik dalam bentuk tenaga, waktu, uang maupun material lainnya, memunculkan kelembagaan lokal, baik yang dulu sudah ada maupun bentukan baru.

Dengan adanya pemetaan partisipatif diharapkan bisa menjadi pembuka jalan upaya-upaya masyarakat dalam menginventarisis, mengumpulkan, menyelidiki dan mengembangkan kekayaan ruang yang dimiliki oleh masyarakat nusantara, khususnya petani, nelayan dan masyarakat adat.

Dibidang pertanahan dalam mewujudkan Tertib Administrasi Pertanahan masih dipersimpangan jalan, karena masih banyaknya permasalahan yang muncul terkait dengan sengketa kepemilikan dan sengketa duplikasi alat bukti kepemilikan tanah. Dalam upaya untuk percepatan pembangunan data spasial yang berkualitas telah dilakukan usaha-usaha melalui penyelenggaraan pendaftaran tanah untuk menjamin kepastian hukum hak-hak atas tanah.

\section{Kesimpulan}

Kebijakan Satu Peta atau One Map Policy dalam rangka mewujudkan Tertib Administrasi Pertanahan masih dipersimpangan jalan, karena masih banyaknya permasalahan yang muncul terkait dengan sengketa kepemilikan dan sengketa duplikasi alat bukti kepemilikan tanah. Dalam upaya untuk percepatan pembangunan data spasial yang berkualitas telah dilakukan usaha-usaha melalui penyelenggaraan pendaftaran tanah untuk menjamin kepastian hukum hak-hak atas tanah.

\section{Daftar Pustaka}

Opini, "Kebijakan Satu Peta, Pemetaan Kawasan Hutan Libatkan Publik, Bisnis Indonesia, Selasa 26 Agustus 2014.

Opini, "Perpres No.9/2016: Pemerintah Bentuk Tim Percepatan Kebijakan Satu Peta", Humas Sekretariat Kabinet Republik Indonesia, diposting pada: 22 Feb 2016, diunduh 6 Mei 2019, 12.50 WIB

Aloysius Susanto, Kebijakan Satu Peta Momentum Reformasi Penyelenggaraan Informasi Geosapasial Nasional, Jurnal, Seminar Nasional, 2016, hlm.24 
Boedi Harsono, Sejarah Pembentukan Undang-Undang Pokok Agraria, Isi dan Pelaksanaannya, (Jambatan : Jakarta, 2008), hlm 9-16

Cegah Sengketa Lahan, Jokowi Minta "One Map Policy" Segera Dibuat, Kompas.com, Rabu, 24 Agustus 2016|16.01 WIB, diunduh 6 Mei 2019, 13.00 WIB.

Chip Fay \& Martua Sirait, "Kerangka Hukum Negara dalam Mengatur Agraria dan Kehutanan Indonesia: Mempertanyakan Sistem Ganda Kewenangan atas Penguasaan Tanah", ICRAF Southeast Asia Working Paper, No. 2005_3, Paper dipresentasikan dalam "The International Conference on Land Tenure", Jakarta, 11-13 October 2004.

Hepi Hapsari, Pemetaan Partisipatif Potensi Desa, (Surabaya: Jurnal Teknik Geomatikal, Instiutut Teknologi Surabaya, 2017), hlm.1

Kasmito Widodo, Kepala BWRA, Jakarta Desember 2017

Kebijakan Satu Peta Minimalkan Sengketa Tanah, DKI Jakarta, Deputi Gubernur Bidang Tata Ruang Dan Lingkungan Hidup, taruhl.com>kliping, 3 September 2018, diunduh 5 Mei 2019, 12.00 WIB

Sulaiman Daud, Pemetaan Partisipatif, (jurnal Wacana, Edisi 15, Academia Edu, 2013), hlm.4

Tentang Percepatan Kebijakan Satu Peta (PKPS), Sekretariat Tim Percepatan Kebijakan Satu Peta, satupeta.go.id, diunduh 5 Mei 2019, 12.34 WIB

Tentang Percepatan Kebijakan Satu Peta (PKPS), Sekretariat Tim Percepatan Kebijakan Satu Peta, satupeta.go.id, diunduh 5 Mei 2019, 12.34 WIB 